\title{
The role of cultural diversity and communal participation in wetland management in Brazil
}

\author{
A.S. Diegues \\ Wetlands Research and Conservation Programme, Instituto Oceanografico, USP, Cidade Lniversitaria, Butanta, \\ CEP 05508, Sao Paulo (Brazil)
}

(Accepted for publication 23 August 1990)

\begin{abstract}
Diegues, A.S., 1991. The role of cultural diversity and communal participation in wetland management in Brazil. Landscape Urban Plann., 20: 61-66.

This article compares the livelihood strategies of two populations living in different Brazilian wetlands: the fishermen of the coastal floodplain of Marituba, at the mouth of S. Francisco River and the rubber-tappers of the Guaporé Valley. Both communities utilize the renewable resources of the wetlands on a traditional basis: fishery, small-scale agriculture and handicraft in Marituba, and latex, Brazilian nuts and fishery in Guaporé Valley. Both communities are in the process of rapid and intense socioeconomic and biological change. In Marituba, the sugar-cane plantations and the capital-intensive irrigation schemes are threatening the existence of the varzea (floodplain); in Guaporé, rapid deforestation is threatening the livelihoods of local communities. The reaction of these communities is similar: both are fighting for the conservation of the wetland ecosystems as conditions for the survival of their culture and way of life.
\end{abstract}

\section{INTRODUCTION}

Most of the literature on people's participation refers to the need to involve the local population in specific development or conservation projects. These projects are frequently designed by outsiders (consultants, technicians, agencies), thereby aiming at an improvement of the living conditions or environmental situation of local populations through technological or socioeconomic changes. These projects assume that the so-called traditional societies are necessarily static and need to undergo changes from outside to attain "development".

Development is often regarded as a process induced from outside and managed by "modern" local elites. This type of development leads to "modernization" usually without benefitting local populations. In general, only a small local elite takes advantage of the economic growth.

In this modernization context it is assumed that peasant communities oppose changes because of their traditional values. Studies in Brazil (Forman, 1970; Diegues, 1983) and in other parts of the world have shown that peasants are open to changes, provided that they benefit from the outcome of the process and that the risks of implementing innovations do not threaten their livelihood.

According to the modernization theory, traditional management techniques are primitive and not effective and need to be changed into modern ones. It is true that these management techniques are developed after a long process of ecological and cultural adaptation and do respond to a situation where the demand for renewable resources is not high. When a higher demand is introduced, a more intensive use of 
natural resources may take place leading to overexploitation. As a result, these traditional and previously efficient management techniques are abandoned by the local population (Bourgoignie, 1972).

There are many examples in Brazil where traditional wetland management is known to be ecologically sound, economically viable and socially desirable. They are an essential pattern of the relationship of the traditional human communities with the environment. Many of these techniques and approaches naturally involve the participation of the population in managing the wetland habitats and their natural resources (Diegues, 1988).

We present two case studies in which the local population opposed both large state companies and latifundia interests that were threatening their living as well as their traditional management of renewable natural resources. (Both case studies are part of ongoing research undertaken by the Programme on Research and Management of Wetlands in Brazil (University of S. Paulo-IUCN-Ford Foundation ) )

\section{CASE STUDY 1: WETLANDS OF MARITUBA AND THE PARTICIPATION OF LOCAL POPULATION IN THEIR CONSERVATION}

The first case study refers to the resistance of fishermen and peasants to the conversion of a large floodplain into capital-intensive irrigated rice plantations.

Marituba is a "varzea" (floodplain) near the mouth of S. Francisco River in the northeast of Brazil (see Fig. 1). It encompasses about 100 $\mathrm{km}^{2}$ of marshes, a result of the periodical flooding of the river. It is located at the left side of the S. Francisco River, in the State of Alagoas and it is formed by river and coastal sediments from the Cainozoic Period. The swamp is crossed by the Barreiras Canal (some $20 \mathrm{~km}$ long) that connects the $\mathrm{S}$. Francisco River with the Marituba River. This natural canal plays an important role because it is used by many fish species to reach the lakes inside the marsh. The most important lake is Lago dos Peixes, well-known for its abundant fish resources. The vegetation of the swamp includes several species of palm trees that are used by the local population for building thatched roof houses. medicine, food, etc. The Varzea da Marituba are also important habitats for several fish species, birds and small wild animals.

There are some 400 families living in two villages: Marituba de Baixo and Marituba de Cima. In the past, the dwellers lived almost exclusively on fishing. They were the owners of the swamps and the surrounding land. Because of the low value of these lands and according to tradition, they were given to the Catholic Church, thus becoming the patrimony of the Diocese of Penedo (Alagoas). The administrator of the Church lent small plots back to the peasants for subsistence agriculture. However, a sugar-cane factory started to expand its plantations over the Marituba land. Some 12 years ago, the Church decided to sell the land to the sugar-cane factory and the peasants were left with only their thatched-roof houses.

The peasants, via the Rural Workers Union, opposed their eviction from the land, arguing that it belonged to their ancestors. After a long process, they regained part of their land. The sugar-cane factory, Paisa, however went on to enlarge the plantation up to the edge of the swamps, thus threatening the swamps with pesticides and toxic wastes (vinhoto). After losing part of their land, some Marituba families became wage earners in the plantation: because of the low level of wages, these families became even poorer. Because of these factors the productivity of fishing is low, and most of the families have to supplement their income by small-scale agricultural activities and by seasonal labour for Usina Paisa.

In addition to the impact of the sugar-cane plantation, the Marituba swamps and its population are under a more serious threat: the 


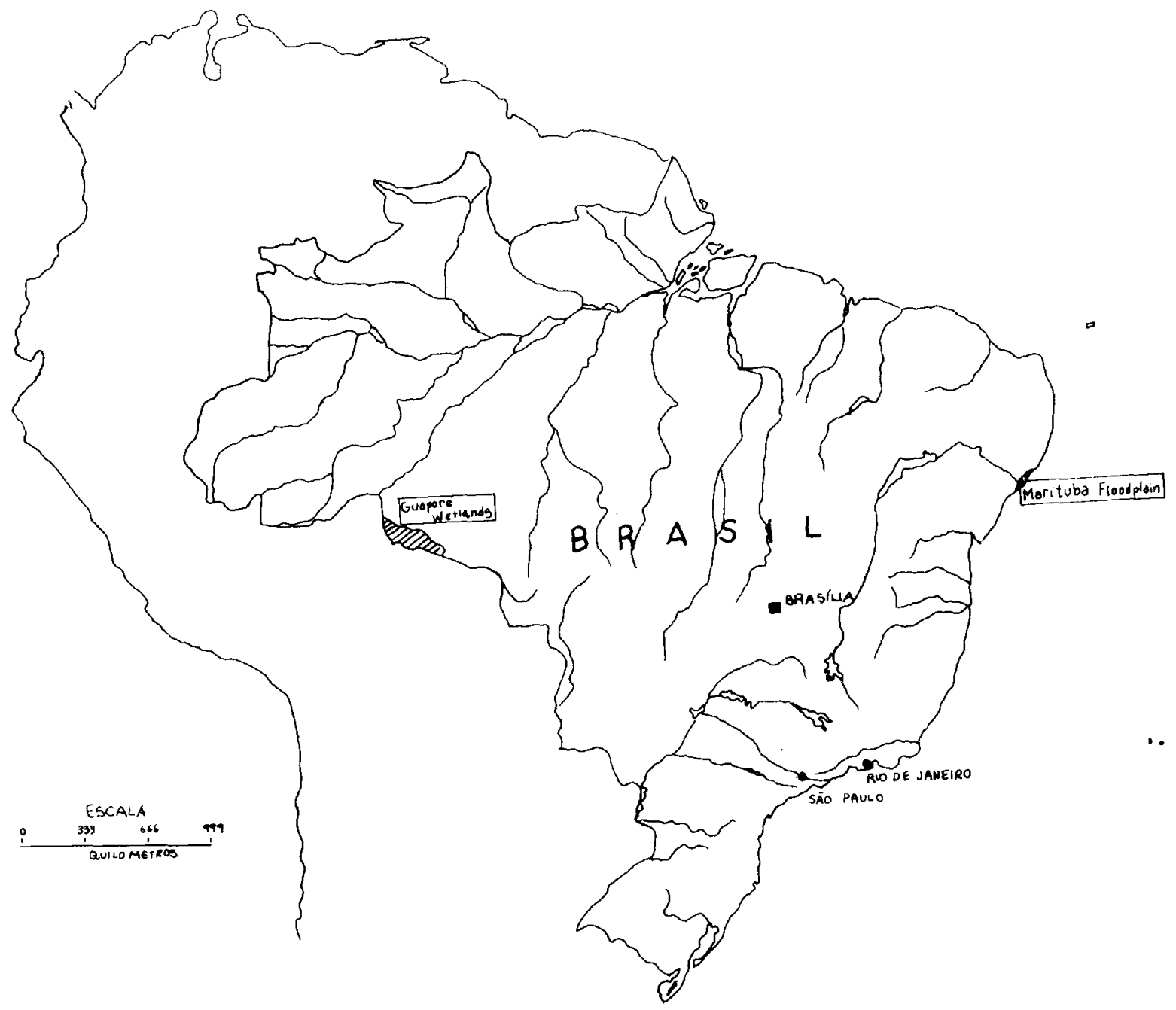

Fig. 1. Case study areas.

conversion of the varzea into irrigated rice fields by a State Development Agency CODEVASF. This company has already converted several large swamps of the S. Francisco River into rice field projects. In the already established projects the transformation of the swamps is complete and the whole water regime has been changed. In a project called Betume ( $10000 \mathrm{ha}$ ), the CODEVASF closed the water access to the lagoons and stopped fish migration. As a result, fish stocks diminished and local fishermen lost their livelihood. In ad- dition to these serious environmental impacts, the local population has also suffered from the conversion of the wetlands. They lost their land and were forced to live on the outskirts of the project area. They were temporarily employed in the build-up of the irrigated fields but few were allowed plots. Rice plots with an irrigation infrastructure were given to outside farmers.

In 1985 CODEVASF decided to start a new project in the Marituba swamps that would mean a complete transformation of the Var- 
zea, and the disruption of the canal between the S. Francisco River and the Marituba floodplain, and consequently of fisheries. The peasants/fishermen would be resettled elsewhere. The population, with a long tradition of opposing the latifundia also strongly opposed this project. They argued correctly that the project would not benefit them at all, but instead would destroy their livelihood: fishing in the swamps. As result of their opposition, the Government of Alagoas declared Marituba an Environmental Protection Area, where large projects can only be implemented after an Environmental Impact Analysis. CODEVASF did not entirely abandon the project but started other projects close to Marituba swamp.

In order to reinforce local organization and to assess the economic value of the swamps, the Programme for Research and Management of Wetlands in Brazil (USP-IUCN-Ford Foundation ) is supporting the activities of an interdisciplinary research team from the Federal University of Sergipe. This team is presently surveying the natural resources of the swamps and the way local populations use them. One of the main purposes is to show how important these wetlands are for the survival of the local population. At the same time, the project aims at supporting local initiatives for a sustainable use of natural resources (fisheries management, aquaculture, etc.). The technical assistance that is provided by the research group will be of great value to the local population in its struggle against the conversion of the valuable wetlands of Marituba.

\section{CASE STUDY 2: THE WETLANDS OF GUAPORÉ VALLEY AND TRADITIONAL USES BY THE LOCAL POPULATION}

The Guaporé Valley is a large wetland area ( > 1500000 ha) in the Amazonian State of Rondonia, near the border with Bolivia (see Fig. 1).

The state of Rondonia is the Amazonian State with the highest rate of forest cutting. having lost already more than $23 \%$ of its tropical forest. This is done mainly for the expansion of cattle-raising and agricultural settlement projects subsidized by the Government. The forest clearing activities are approaching the until now, well preserved Valley of Guaporé River, threatening Indian Reserves ( $\mathrm{Pa}$ caas-Novas) and the local Biological Reserve. The result of the forest cutting is the destruction of an area of great economic potential. represented by rubber latex, nut trees, medicinal plants and an important genetic and biological diversity.

The Valley is inhabited by rubber-tappers, nut gatherers, Indians from various tribes and by a sparse riverain population. They live in small, scattered settlements along the rivers or in the forest. Their livelihood is assured by the use and sale of more than 30 different forest products without the need for logging. The recent occupation of the region by farmers from the southern provinces has resulted in the traditional population being expelled, particularly by large latifundia that use fiscal incentives for establishing cattle ranches. Because of this, over 50000 rubber-tappers from Rondonia have crossed the border to live and work in Bolivia.

Although the Guaporé Valley has not so many rubber trees as in the State of Acre, where over 500000 people earn their living from collecting latex from wild rubber trees, this is an important activity in Rondonia. Because of the threat to their livelihood, the seringueiros (rubber-tappers), organized themselves into unions in the early 1970 s. They started peacefully resisting eviction from the rubber-tree lands through "empates" - sitting-down in front of the sawing machines in order to avoid wood-cutting. The work of the National Council of Rubber-Tappers in favour of the conservation of the Amazonas Forest met strong opposition from powerful economic lobbies of big landowners, and many leaders, including the worldwide-known Chico Mendes, were brutally killed. 
The death of Chico Mendes aroused great national and international support for the struggle of the seringueiros against the destruction of the Amazon forest. It also made clear that the tropical forest will not be protected and sustainably used without taking into consideration the interests of traditional communities, particularly rubber-tappers and Indians, who make their living from the wise use of the forest.

As part of the National Rubber-Tappers Movement, the people of Guaporé are organizing themselves to resist the destruction of the forest. In March 1989, a first meeting took place in Guajara Mirim in order to organize the rubber-tappers movement in the area. One of the main elements of their strategy is the establishment of "extractive reserves". These are protected areas to be sustainably managed by the communities that live in and know the forest. Being in possession of land use rights, the tappers cooperatives can protect the forest area against logging, agriculture and cattle raising. Legally protected areas under local control are an attractive proposition for communities facing expulsion by cattle ranchers, large landowners or settlement projects. The legal rights also will be an incentive to increase production of valuable forest goods.

The Rubber-Tappers Cooperative movement also promotes the marketing of extractive products, the removal of subsidies for unsustainable land uses, access to credit for extractive products and the improvement of health services and education.

The establishment of extractive reserves in the Guapore Valley is essential for the sustainable use of the wetland resources. In this connection the Programme on Research and Management of Wetlands in Brazil started a set of activities in Guaporé Valley related to research and management of wetlands, in coordination with the Institute of Anthropology and Environment (IAMA, 1989). An interdisciplinary survey is being undertaken in order to evaluate the natural resources of the wetlands, the uses made by the local population, and the threats to the resources. On the basis of this survey, a sustainable development strategy will be proposed in close coordination with the local branch of the National Rubber-Tappers Movement. This strategy includes the demarcation of extractive reserves, aiming at a sustainable use of the resources. These reserves are an alternative, but not an exclusive model for the national parks from which traditional populations are excluded.

There is growing concern that an overall strategy for a sustainable development of the Amazonian Region should be reached. It is becoming clear that the present pattern of land occupation is ecologically destructive and socially unjust. Although the creation of national parks may be considered an important element to maintain biological diversity, it does not offer solutions for all the serious problems connected with the development process of the region. Most of the national parks in the Amazon, because of the lack of surveillance, are threatened by poachers, mining and logging companies, settlement projects, etc. It is crucial to harmonize socioeconomic development with the conservation of natural resources and habitats. A sustainable use of the forest resources - not based on logging and conversion to other land use - is essential in Guaporé Valley.

In this context, the extractive reserves should be part of an overall solution for the sustainable development of the Guaporé wetlands. This should include a management plan that would indicate clearly the various potentials and constraints of the area.

\section{CONCLUSIONS}

The two case studies show how important the organization of the local population is in conserving wetlands and their resources. In the case of Marituba, the local population decided to oppose the conversion of the wetland ecosystem into capital-intensive rice plantations. 
They felt that using the renewable resources of the floodplain would bring them more benefit than the establishment of irrigated rice fields. They felt that the conversion of the floodplain would destroy their way of life and the solidarity that exists among those using the natural resources of the swamp. Based on the experience of previous irrigated rice schemes by CODEVASF, local inhabitants are convinced that they would be forced to abandon their land and live in miserable shacks on the border of the area. Their struggle is not yet over but a first victory has been achieved by the declaration of the Environmental Protected Area. Their success, however, will ultimately depend on their capability of organizing themselves and using the natural resources of the wetlands in a sustainable way.

The case study of Guaporé wetlands indicates a new strategy for the sustainable development of the area, based on the establishment of extractive reserves, managed and controlled by the users: rubber-tappers, nut collectors, Indian tribes and the riverain population. The creation of extractive reserves will require specific legislation, and will depend on the pressure exercised by the National Council of Rubber Tappers and their new allies: the Indian Tribes of the Amazon. International assistance will certainly be needed to implement the strategy, as the opposing forces (mining, cattle ranching) are enormous. This strategy, however, has gained great support among important sectors of Brazilian society, especially after the murder of the rubber-tappers' leaders in these last months.

These examples also made clear that the organization of the users of the wetlands is more important than any outside induced development project. It has also made clear that conservation and economic uses of the wetlands resources are compatible, provided that the culture and the wishes of the local population are taken into account. In this context, the maintenance of a diversity of ecosystems and species is closely related to the survival of the important cultural diversity existing in Brazil.

\section{REFERENCES}

Bourgoignie, G., 1972. Perspectives en Ecologie Humaine. Editions Universitaires. Paris.

Diegues, A. 1983. Pescadores. Camponesese Trabalhadores do Mar. Editora Atica, S. Paulo

Diegues. A. 1988. Biological Diversity and Traditional (ultures in Coastal Wetlands of Brazil. Programme on Wetlands Conservation (IOUSP/FORD F./IUCN) S. Paulo.

Forman, S., 1970. The raft fishermen: Tradition and Change in the Brazilian Peasant Economy. Indiana University Press.

IAMA/Programa de Areas Umidas, 1989. Levantamento preliminar de informaçoes socio-ambientais: populçoes tradiçionais, preservaçao e uso de recursos naturais, Sao Paulo. 